The Labore Journal of Economics

Special Edition (September 2007)

\title{
Determinants of Female Labor Force Participation in Pakistan An Empirical Analysis of PSLM (2004-05) Micro Data
}

\author{
Mehak Ejaz*
}

\section{Abstract}

This paper seeks to identify the major determinants of female labor force participation in Pakistan, specifically with reference to rural and urban areas. Limited dependent variable techniques (Logit and Probit) are utilized to determine the factors affecting female labor force participation. This analysis uses data taken from the PSLM (Pakistan Social and Living Standards Measurement Survey, 2004-05) which measure individual and household characteristics of females between the ages of 15-49. Empirical results suggest that age, educational attainment and marital status have significant and positive effects on female labor force participation (FLFP). When women belong to the nuclear family and have access to vehicles, they are more likely are they to participate in economic activities, whereas a large number of children and the availability of home appliances reduces the probability of FLFP. The results imply that reducing the child care burden on females and facilitating educational attainment would lead to a higher labor force participation rate for females in Pakistan.

\section{Introduction}

The economically active population, or labor force, is a group of people who produce goods and services to meet the requirements of society. Pakistan has a relatively low labor force ${ }^{1}$ participation rate owing to the lower percentage of women in the work force. Therefore this is a major issue concerning the development of Pakistan.

According to the Labor Force Survey, the female labor participation rate in 2004-05 was only 14.6\%. According to the Economic Survey, the

\footnotetext{
* The author is a Research Associate at the Centre for Research, Lahore School of Economics, Lahore.

${ }^{1}$ In Pakistan, the labor force is defined as all persons ten years of age and above who are working or looking for work for cash or kind, one week prior to the date of enumeration.
} 
female labor force participation rate has shown a considerable rise of $8 \%$, over the past three decades. However, as compared to other South Asian countries, the LFP is still very low. ${ }^{2}$

Labor Force Participation Rates, 1973 - 2006

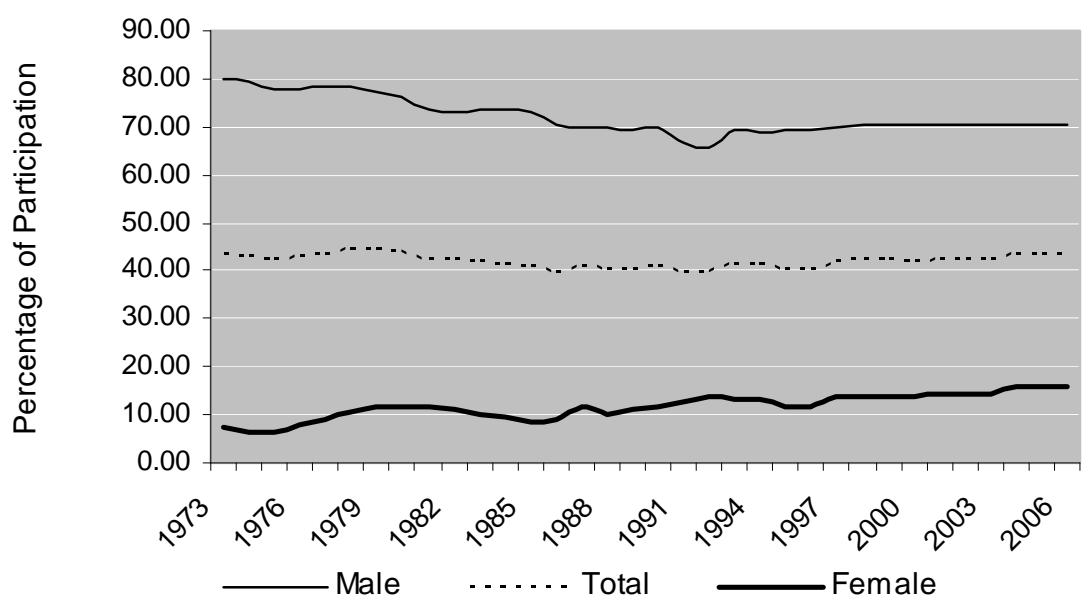

There are several explanations for the low rate of female labor participation in Pakistan. A few of these reasons are the early age marriages, the strong negative social and cultural influences on the free movement of women and the absence of an organized labor market. This paper is an attempt to highlight the major factors that hinder women from joining the labor force in Pakistan.

Earlier studies have emphasized the decision making aspect in Pakistan though the focus on determinants is somewhat lacking. The main sources of labor force and employment statistics are the Population Census and Labor Force Survey, conducted by Federal Bureau of Statistics on an annual basis.

The situation of women in Pakistan varies according to their geographical location and class. Women who belong to urban areas and the upper strata of society are in a better condition as they have greater opportunities for higher education and seeking professional work. Almost $75 \%$ of the female population belong to rural areas, and suffer from poor health issues, mainly due to constant motherhood. All Pakistani women

\footnotetext{
${ }^{2}$ According to the World Bank Report of 2002 the labor force participation rate was $42 \%$ in Bangladesh, 32\% in India and Bhutan, 41\% in Nepal and 37\% in Sri Lanka.
} 
remain structurally disadvantaged as a result of legal, social and cultural discrimination.

On the basis of this background, women's economic activities and the determinants regarding paid employment are examined by analyzing different factors pertaining to the household.

According to our knowledge, there is no specific study to date that has incorporated the socioeconomic and cultural issues as well as household related factors. This study explores the causal factors, determinants and issues that are major hurdles for women's participation in the labor force and hence, the economic development of Pakistan. After the analysis on HIES (1999) data, no empirical study has analyzed such a large number of observations. In this study, the total number of observations is 115,077 , of which 72,099 come from rural areas and the rest of the 42,978 observations pertain to the urban areas of Pakistan. We believe that this study will prove to be a contribution towards the existing literature.

The paper is divided into six sections. The next section presents a comprehensive literature review which highlights the main ideas, theory, findings and shortcomings of the relevant work conducted in this field. The third section provides the theoretical framework, based on which the methodology is developed. A detailed discussion of the Probit and Logit models is also included in this section. The fourth section explains the data source and the description of relevant variables, while empirical results and the findings of the study are discussed in the fifth section. This section also includes a brief comparison of the FLFP rates of Pakistan, India and Bangladesh. Section six concludes the paper, and deals with some policy implications.

\section{Review of Literature}

Over the years, many researchers have dealt with the issue of female labor force participation. Estimating the labor supply curve and determinants of productivity has been a common topic of interest among many economists and sociologists. This section attempts to review the literature pertaining to the labor supply theory, as well as issues regarding female labor force participation. ${ }^{3}$

\footnotetext{
${ }^{3}$ The literature entails cases both within and outside Pakistan.
} 
Berndt (1990) states that the labor force participation rate of women varies by age and has considerably increased for all age groups during the past three decades. He extends the neoclassical labor supply framework to encompass the household, while addressing issues such as the discouraged worker hypothesis, and the male chauvinist model. He points out that most first generation studies show that female labor supply is more responsive to changes in wage rates and property income, as compared to male labor supply. The second generation of studies points out that the elasticity of these estimates is greater. ${ }^{4}$ Nakamura and Nakamura (1979) contradict some of these results. They find the female labor supply to be unresponsive to changes in wage rates. Hausman (1981) implies that progressive income taxes reduce a wife's labor supply by decreasing the net after tax wage. Mroz (1987) essentially follows up on the Nakamura and Nakamura study relating to the responsiveness of female labor supply. He notes the large diversity of reported estimates of female labor supply responses to variations in wage rates and income. He concludes that the estimated uncompensated wage effect is positive but rather small. Moreover, he finds the income effect to be negative and fairly small. These results suggest that the modest sensitivity of married women's labor supply is not very different from the labor supply of prime aged married males. The backward bending labor supply curve in essence holds true for females as well as males.' Hence the results are consistent with the view that a woman's preference for work is an unobserved omitted variable that affects her current as well as previous labor market participation. Robinson and Tomes (1985) also support the conclusions of Nakamura and Nakamura (1981), as they conduct their study on Canadian women. The estimates obtained in this study are larger than those of the Nakamuras, suggesting that the income elasticity of demand for leisure is greater relative to the substitution effect for women, than that for men. These results indicate that the contrasting patterns of female and male labor supply curves correspond to the differential responsiveness of male and female participation to opportunities, rather than the hours worked.

A major factor that reduces the female labor force participation rate relates to the fact that women essentially tend to concentrate more on providing services to the household after they get married. This is a crucial issue and has been dealt with by various researchers worldwide. Bradbury and Katz (2005), identify a recent decline in female labor force participation, specifically among well educated women with children. $\mathrm{He}$

\footnotetext{
${ }^{4}$ Heckman, Killingsworth and Macurdy(1981).

${ }^{5}$ Nakamura and Nakamura (1981)
} 
finds that unobserved and unpredictable factors contribute towards a decline in the participation of women.

Dynamic, lifetime models of labor supply have also been of considerable debate in the economic literature. In such models, economic agents act in a way as to consider the future consequences of their present actions. Mincer (1962) attempted to reinterpret the static analyses of labor supply to include lifetime variables. ${ }^{6} \mathrm{He}$ finds that family income has no effect on the wife's demand for leisure. His results also indicate that the number of children have a significant effect on a female's lifetime labor supply curve. Moreover, he concluded that the probability of labor force participation is inversely related to lifetime wealth measures.

Duleep and Sanders (1994) present similar results and examine the current labor supply of 25-44 year old married women in the United States. They are further classified into native-born whites, Asian immigrants, Hispanic immigrants, and European immigrants. The results of this study show that the employment rates of women are inversely proportional to the number of children and age of the youngest child, when no account of past work is taken. There are significant differences across the groups of women whereby native born white women are less responsive to the number of children and age of the youngest child. However, when women are classified according to whether they worked in 1979, the number of children does not seem to be associated with the propensity to start or continue working.

Heckman (1974) presents an interesting analysis of the value a woman places on her time (asking wage or shadow price of time). The results indicate that the estimated effect of one child less than six raises the asking wage by $15 \%$. Increases in net assets, the husband's wage rate and woman's education has a positive effect on the asking wage.

Several studies have been conducted on the situation of Pakistani women, and factors affecting their participation rate have been analyzed. Shah (1986) analyzed the changing role of women in Pakistan between 1951 and 1981. He concluded that the labor force participation decision of women is inversely related to the socio-economic status of the family. Shah et al (1976) examined some of the socio-economic and demographic factors that determine the labor force participation decision of women in Pakistan. They attempt to analyze results for all the four provinces of Pakistan. Their

\footnotetext{
${ }^{6}$ Variables such as consumption, leisure, work at home, wages, budget constraints and time were translated into lifetime variables.
} 
results show that labor force participation has a significant and inverse relationship with the nuclear family, as well as the child-woman ratio However, a positive relationship has been found with marital status, dependency ratio and literacy rates. The positive relationship with marital status however, is in contrast to most of the earlier studies. Rashid et al (1989) present a case study of Pakistan in which they attempt to analyze the demographic and socio economic factors affecting the labor supply of women. The results show that LFP is positively related to increases in expected earnings, wages and level of education. An interesting observation by these researchers is the fact that the presence of a male figure in the household reduces the likelihood of female participation in the labor force. However, the presence of other females in the house increases the probability that a woman will work.

Ibraz (1993) confines his study to the rural areas of Pakistan, and observes that various cultural issues such as the observation of purdab in an Islamic society restrains a woman from active participation in the labor force.

Naqvi and Shahnaz (2002) have conducted a similar study of Pakistan and have identified the household related factors that lead to women's participation in economic activities. The innovative aspect of the paper is that it relates women's decision to participate in economic activities with their empowerment. The empirical findings of this paper suggest that the economic participation of women is significantly influenced by factors such as age, education and marital status.

It can be inferred from the literature that various economic as well as sociological factors have a profound effect on the labor force participation decision of women. However, it is felt that some important factors have been neglected in these studies, especially those relating to household issues. This study, therefore, attempts to identify and present a comprehensive analysis of all such factors.

It is expected that this study will contribute to the economic literature in a significant way by improving upon the previous studies and also identifying the factors affecting LFP in Pakistan. 


\section{Theoretical Framework and Methodology}

\section{The Probit and Logit Models}

Economists frequently encounter the research problem whereby the dependent variable of the structural model is not directly observed. The actual value observed may be dependent on the values of other variables or alternatively may observe a variable that takes on values related to the underlying unobserved dependent variables. For these models, ordinary least squares or standard economic estimators are not appropriate, because of the limited or qualitative nature of the observed dependent variable.

General equation

$$
\mathrm{Y}_{i}=f\left(\mathrm{X}_{1} \ldots \ldots \mathrm{X}_{i}\right)
$$

where, $Y_{i}$ denotes female labor force participation (FLFP). $X_{1} \ldots \ldots . X_{n}$ represent various determining factors leading to female participating in the labor force.

$$
y_{i}^{*}=\beta_{0}+\sum_{j=1}^{k} \beta_{j} \chi_{i j}+\varepsilon_{i}
$$

where $y_{i}^{*}$ is not observed. It is a latent variable. What we observe is a dummy variable $y_{i}$ defined by

$$
\begin{aligned}
y_{i} & =1 & \text { if } y_{i}^{*}>0 \\
& =0 & \text { otherwise }
\end{aligned}
$$

$y$ is equal to 1 if the female participates in economic activity and equal to zero if she does not. $\beta$ is a row vector of parameters and $\varepsilon_{i}$ is normally distributed with mean 0 .

The probit and logit models differ in the specification of the distribution of the error term $u$ in the equation ${ }^{7}$, such that the former assumes that errors are normally distributed and the latter assumes that errors follow the logistic distribution.

\footnotetext{
${ }^{7}$ Maddala (2001), Gujrati (1995)and Berndt (1991)
} 


\section{Data Source}

The study is based on cross-sectional data from the Pakistan Social and Living Standards Measurement (PSLM) Survey - HIES (2004$05)$, concentrating on the sample of women aged 15-49. The total number of households were $73,429^{8}$ of which 115,077 observations pertain to females aged 15-49. These observations are used in the empirical analysis.

Given that the logistic postulates:

Prob [female in work force $]=\frac{1}{1+e^{-z}}$

$$
\mathrm{Z}=\beta_{0}+\beta_{1} \mathrm{X}_{1}+\beta_{2} \mathrm{X}_{2}+\ldots \ldots \ldots+\beta_{k} \mathrm{X}_{k}
$$

Each $\beta_{i}$ is shown to be:

$$
\frac{\partial \log (\text { oddsratio })}{\partial \chi_{i}}{ }^{9}=-\beta_{i}{ }^{10}
$$

For continuous variables, it is possible to compute the change in probability when the variable, $\mathrm{X}_{j}$ is increased by one unit. This change can be calculated using:

$$
\frac{\partial P}{\partial X_{j}}=\frac{B_{j} e^{-z}}{\left[1+e^{-z}\right]^{2}}
$$

\footnotetext{
${ }^{8}$ Usman Sikander (Research Officer, Lahore School of Economics) helped in processing the micro level data

${ }^{9}$ Odds ratio $=\mathrm{P}$ [female in work force $] / \mathrm{P}$ [female not in work force $]=e^{-z}$

${ }^{10} \beta_{i}$ provides a measure of change in the logarithm of the odds ratio of the chance of the female working to not working.
} 
The following is the list of variables used in the estimation of the model:

Notation and description of variables in the econometric model

\begin{tabular}{ll}
\hline Dependent variable & $\begin{array}{l}\text { Labor force participation }(\mathrm{LFP}) \\
\text { worked/looking for work }\end{array}$ \\
&
\end{tabular}

Independent variables

Age Age of the female respondent

Marital Marital status (dummy variable)

$1=$ unmarried; $0=$ married women

(Unmarried includes single, divorced and widowed women)

School Years of schooling

H-Income Head's income

Children No. of children

Infants No. of children younger than 5 years

W-people No. of working people in the family

F-size Size of family (No. of family members including respondent)

F-type Type of family (dummy variable) $1=$ nuclear family, $0=$ otherwise

Location Rura1/Urban (dummy variable)

$1=$ urban, $0=$ rural

Asset-agric Ownership of agricultural land

Tech Weighted index of appliances

Cycle Own cycle $=1, \quad 0=$ otherwise 


\section{Empirical Results}

Table-1: Labor Force Participation of Female

\begin{tabular}{ccccccc}
\hline & \multicolumn{3}{c}{ Frequency } & \multicolumn{3}{c}{ Percent } \\
\hline & Rural & Urban & Total & Rural & Urban & Total \\
\hline 0.00 & 59243 & 39033 & 98276 & $82.2 \%$ & $90.8 \%$ & $85.4 \%$ \\
1.00 & 12856 & 3945 & 16801 & $17.8 \%$ & $9.2 \%$ & $14.6 \%$ \\
Total & 72099 & 42978 & 115077 & $100.0 \%$ & $100.0 \%$ & $100.0 \%$ \\
\hline
\end{tabular}

Table-2: Results of Overall Pakistan ${ }^{11}$

\begin{tabular}{lcccc}
\hline Variable Description & \multicolumn{2}{c}{ Probit } & \multicolumn{2}{c}{ Logit } \\
\hline & Coefficients & $\begin{array}{c}\text { Marginal } \\
\text { Effects }\end{array}$ & Coefficients & $\begin{array}{c}\text { Marginal } \\
\text { Effects }\end{array}$ \\
\hline Constant & $-1.878^{*}$ & -0.349 & $-3.266^{*}$ & -0.322 \\
Age of the female & $0.017^{*}$ & 0.003 & $0.031^{*}$ & 0.003 \\
Married=1,Otherwise0 & $-0.214^{*}$ & -0.040 & $-0.425^{*}$ & -0.042 \\
Years of Schooling & $0.022^{*}$ & 0.004 & $0.046^{*}$ & 0.005 \\
No. of working people in family & $0.511^{*}$ & 0.095 & $0.994^{*}$ & 0.098 \\
Family Size & $-0.134^{*}$ & -0.025 & $-0.289^{*}$ & -0.029 \\
Nuclear=1,Otherwise 0 & $0.097^{*}$ & 0.018 & $0.219^{*}$ & 0.022 \\
if own Car, Motorcycle, & $0.072^{*}$ & 0.013 & $0.119^{*}$ & 0.012 \\
Cycle=1,Otherwise 0 & & & & \\
Weighted index of home & $-0.235^{*}$ & -0.044 & $-0.428^{*}$ & -0.042 \\
appliances & & & & \\
If Female head=1, Otherwise 0 & $0.497^{*}$ & 0.092 & $0.971^{*}$ & 0.096 \\
Infant+ children per female & $0.365^{*}$ & 0.068 & $0.754^{*}$ & 0.074 \\
Infant+ children per female sqr & $-0.044^{*}$ & -0.008 & $-0.089^{*}$ & -0.009 \\
No. of observations & 115077 & & 115077 & \\
$\mathrm{R}^{2}$ & 0.2259 & & 0.2361 & \\
Scaled R ${ }^{2}$ & 0.1687 & & 0.1773 & \\
Fraction of Correct Predictions & 0.8719 & & 0.8735 & \\
\hline
\end{tabular}

$*, * *, * * *$ presents significance at $1 \%, 5 \%$, and $10 \%$ level respectively

\footnotetext{
${ }^{11}$ Sayed Kalim Hayder (Senior Research Fellow) helped in the econometric results
} 
Table-3: Results of Urban Areas

\begin{tabular}{|c|c|c|c|c|}
\hline \multirow[t]{2}{*}{ Variable Description } & \multicolumn{2}{|c|}{ Probit } & \multicolumn{2}{|c|}{ Logit } \\
\hline & Coefficients & $\begin{array}{c}\text { Marginal } \\
\text { Effects }\end{array}$ & Coefficients & $\begin{array}{c}\text { Marginal } \\
\text { Effects }\end{array}$ \\
\hline Constant & $-1.878 *$ & -0.340 & $-3.266^{*}$ & -0.31 \\
\hline Age of the female & $0.017^{*}$ & 0.004 & $0.031^{*}$ & 0.00 \\
\hline Married $=1$, Otherwise 0 & $-0.214^{*}$ & -0.062 & $-0.425^{*}$ & -0.06 \\
\hline Years of Schooling & $0.022 *$ & 0.007 & $0.046^{*}$ & 0.01 \\
\hline $\begin{array}{l}\text { No. of working people } \\
\text { in family }\end{array}$ & $0.511^{*}$ & 0.079 & $0.994^{*}$ & 0.08 \\
\hline Family size & $-0.134^{*}$ & -0.022 & $-0.289 *$ & -0.02 \\
\hline Nuclear $=1$, Otherwise 0 & $0.097^{*}$ & 0.028 & $0.219^{*}$ & 0.03 \\
\hline $\begin{array}{l}\text { If own car, Motorcycle, } \\
\text { cycle }=1 \text {, Otherwise } 0\end{array}$ & $0.072 *$ & 0.088 & $0.119 *$ & 0.08 \\
\hline $\begin{array}{l}\text { Weighted index of home } \\
\text { appliances }\end{array}$ & $-0.235^{*}$ & -0.021 & $-0.428^{*}$ & -0.02 \\
\hline $\begin{array}{l}\text { If female } \\
\text { head }=1 \text {, Otherwise } 0\end{array}$ & $0.497^{*}$ & 0.075 & $0.971^{*}$ & 0.07 \\
\hline $\begin{array}{l}\text { Infant+ children per } \\
\text { female }\end{array}$ & $0.365^{*}$ & 0.056 & $0.754^{*}$ & 0.06 \\
\hline $\begin{array}{l}\text { Infant+ children per } \\
\text { female sqr }\end{array}$ & $-0.044^{*}$ & -0.007 & $-0.089 *$ & \\
\hline No. of observations & 42978 & & 42978 & \\
\hline $\mathrm{R}^{2}$ & $2.13 \mathrm{E}-01$ & & 0.2188 & \\
\hline Scaled $\mathrm{R}^{2}$ & $1.62 \mathrm{E}-01$ & & 0.1637 & \\
\hline $\begin{array}{l}\text { Fraction of Correct } \\
\text { Predictions }\end{array}$ & $9.14 \mathrm{E}-01$ & & 0.9153 & \\
\hline
\end{tabular}

$*, * *, * * *$ presents significance at $1 \%, 5 \%$, and $10 \%$ level respectively 
Table-4: Results of Rural Areas

\begin{tabular}{|c|c|c|c|c|}
\hline \multirow[t]{2}{*}{ Variable Description } & \multicolumn{2}{|c|}{ Probit } & \multicolumn{2}{|c|}{ Logit } \\
\hline & Coefficients & $\begin{array}{l}\text { Marginal } \\
\text { Effects }\end{array}$ & Coefficients & $\begin{array}{l}\text { Marginal } \\
\text { Effects }\end{array}$ \\
\hline Constant & $-1.756^{*}$ & -0.376 & -3.039 & -0.352 \\
\hline Age of the female & $0.013^{*}$ & 0.003 & 0.024 & 0.003 \\
\hline Married $=1$,Otherwise 0 & $-0.138 *$ & -0.030 & -0.275 & -0.032 \\
\hline Years of Schooling & $0.014^{*}$ & 0.003 & 0.032 & 0.004 \\
\hline $\begin{array}{l}\text { No. of working people } \\
\text { in family }\end{array}$ & $0.483^{*}$ & 0.103 & 0.923 & 0.107 \\
\hline Family size & $-0.123^{*}$ & -0.026 & -0.258 & -0.030 \\
\hline Nuclear $=1$, Otherwise 0 & $0.097^{*}$ & 0.021 & 0.223 & 0.026 \\
\hline Own Agricultural asset & $0.003^{*}$ & 0.001 & 0.004 & 0.000 \\
\hline Ownership of cattle & $0.001 *$ & 0.000 & 0.002 & 0.000 \\
\hline $\begin{array}{l}\text { If own Car, Motorcycle, } \\
\text { Cycle }=1 \text {,Otherwise } 0\end{array}$ & $0.099 *$ & 0.021 & 0.163 & 0.019 \\
\hline $\begin{array}{l}\text { Weighted Index of home } \\
\text { appliances }\end{array}$ & $-0.206^{*}$ & -0.044 & -0.367 & -0.043 \\
\hline $\begin{array}{l}\text { If female } \\
\text { head=1, otherwise } 0\end{array}$ & $0.481^{*}$ & 0.103 & 0.955 & 0.111 \\
\hline $\begin{array}{l}\text { Infant+ children per } \\
\text { female }\end{array}$ & $0.341^{*}$ & 0.073 & 0.687 & 0.080 \\
\hline $\begin{array}{l}\text { Infant+ children per } \\
\text { female squared }\end{array}$ & $-0.041^{*}$ & -0.009 & -0.081 & -0.009 \\
\hline No. of observations & 72099 & & 72099 & \\
\hline $\mathrm{R}^{2}$ & 0.2302 & & 0.2413 & \\
\hline Scaled $\mathrm{R}^{2}$ & 0.1782 & & 0.1875 & \\
\hline $\begin{array}{l}\text { Fraction of Correct } \\
\text { Predictions }\end{array}$ & 0.8489 & & 0.8506 & \\
\hline
\end{tabular}

$*, * *, * * *$ presents significance at $1 \%, 5 \%$, and $10 \%$ level respectively 


\section{Empirical Findings}

The empirical model highlights the major determinants of female labor force participation (LFP) in Pakistan. Further, in order to give due consideration to regional heterogeneity, the model is estimated for the rural and urban areas as well. A number of potential variables are included in the model on the basis of theoretical models that have been discussed in detail in the section on the literature review. In order to improve the model specification, region specific variables relating to the rural and urban areas are incorporated.

Estimated parameters and mean probability derivatives of the Probit and Logit model for the overall model are reported in Table-2.2. The probability derivatives indicate the change in probability on account of a one-unit change in the given independent variable after holding all the remaining variables constant at their mean.

Female characteristics such as age, marital status, years of schooling, and household characteristics such as the number of working people in the family, nuclear/extended family, ownership of vehicle, female headed household, family size, and availability of home appliances are the significant determinants of female labor force participation in Pakistan. The sample consists of females of the age cohort 15-49 years. The coefficient of age for the Probit and Logit model reflects that with an increase in age, there is a greater likelihood that a female will enter the labor market.

The dummy variable that takes the value of 1 for married and 0 otherwise proves that the significance of marital status affects the LFP. The results indicate that if a woman is married, there is less probability that she will enter the labor force. In Pakistan, married women are less likely to be involved in income generating activities due to their preferences for household activities. Education is also a very important factor in determining the probability that a female would enter the labor force, since education plays an important role in deciding whether to work or not by enhancing job prospects. Empirical studies found that for women, greater educational attainment leads to greater participation in the labor force, but also increases the productivity. As the years of schooling increase, the probability of women's participation in the labor force also increases. Its coefficient is statistically significant. The results suggest that a female that is educated, unmarried and between the ages of 15 and 49 would have the greatest chance of being part of the labor force. In order to understand the participation decisions of women, household characteristics of the female are also included in the model. 
The socioeconomic status of the household plays a very important role in the labor force participation decision of women. It is a general perception that women usually enter into the work force due to financial constraints faced by the household.

Working people in the family also influence female labor force participation positively. This measures the earning capacity of the household as well as outward orientation of the family. As the number of working people increases in a household, members encourage their women to participate in economic activity as well. The greater the number of working people in the family, the higher would be the probability of women participating in the workforce. The demonstration effect may also be one of the reasons for a positive relationship between working people in the family and LFP of females. It is reasonable to infer that owing to the lower income of other family members, a female would move towards the labor market because of financial needs.

A negative association is found between family size and LFP which indicates that a unit increase in family size would decrease the log odd value by 0.134 , signifying a lower incidence of women in the workforce. The existence of patriarchal relations also plays a vital role in hindering the activity of women, as they are dependent on their husband's or father's decisions. The greater the number of people in a household would lead to a higher workload for the female members, as they would be involved in household activities such as fetching water, doing the laundry, preparing food, and looking after the family members.

Another household characteristic, "type of family", also affects the female employment rate. This determinant is used as a dummy variable that takes the value of 1 for a nuclear family and 0 for an extended family. Since the extended family system still exists in Pakistani culture, it is imperative to incorporate this phenomenon by including two categories of families (extended or nuclear). It has been observed from the results that a woman living in a nuclear family is less restricted and more independent in decision making as compared to women living in joint or extended families. The coefficient of this variable is significant and positive which indicates that a woman is more likely to participate in the labor force, perhaps due to fewer dependent family members in a nuclear family..

It is interesting to note that the provision of any kind of vehicle such as motorcycle, cycle or car increases the probability of women entering the labor force. The more you facilitate the women with a conveyance, the more she would feel secure while traveling from home to workplace. Hence, 
ownership of a vehicle by the household has a significant effect on women's decision to participate in the labor force. The availability of home appliances such as a refrigerator, air conditioner, television, VCD/VCR/CD player, and computer has a negative impact on women to work. The impact of this variable can be explained by the financial status as well as the value placed on leisure. The availability of such goods implies higher earnings of the household, which may lead to a greater preference for leisure.

If a household is headed by a female, other female members of the family may feel more empowered. Being a head of the family, she would encourage female participation in an economic activity. Realizing the responsibilities, she could be more likely to join the labor force depending upon the financial needs of her family. There is a positive relationship between female headed households and LFP.

The proxy variable for the number of dependents is defined as the number of infants (children from age 0-5) and number of children (from 610 years of age) per female ${ }^{12}$. It is introduced to find out the impact of dependent children on female participation. With the increase in the number of infants and children, a female is encouraged to participate in the labor force. However, the square of this variable has a negative impact on the probabilities of female labor force participation. The results indicate that for a small number of infants and children per female, the participation rate increases as the number gets larger but increases at a decreasing rate.

Probit and Logit models estimated for urban regions have been quite similar to the results for Pakistan overall. However, an additional variable, technical education, defined as females having degrees in medicine, engineering, computer science, agriculture or M.Phil/Ph.D, has a positive and significant impact on women participating in the labor force in urban areas, mainly due to the fact that women living in urban areas are more likely to obtain technical education. Technical education is not found to be significant in overall Pakistan and its rural areas, whereas it has a significant effect on the urban areas.

In a similar manner, sector specific variables such as ownership of agricultural land and cattle are introduced in the model for rural areas. Both the variables are found to have a positive impact on LFP. The ownership of agricultural land and cattle reflects their assets as well as a source of income. Earnings from agricultural land and cattle add to the household income, and

\footnotetext{
${ }^{12}$ As PLSM is unable to provide information on the infant or children of a specific female, therefore, this variable is a proxy of the number of infant and children per female in the household
} 
the duty of looking after these assets is usually assigned to women. In this way, women are involved in the income generating process of the household. They also serve as a helping hand during the cutting and harvesting period, and are paid for these activities. This maximizes the probability of females working in the labor force. Ownership of agricultural land and cattle are therefore highly significant variables and has a positive impact on the rural female participation rate. These variables, however, turn out to be less significant in the case of overall and urban areas of Pakistan.

\section{Why is the Female Labor Force Participation Rate Lower in Pakistan?}

It is interesting to note that despite the same social and economic background, Pakistan, India and Bangladesh exhibit varying levels of female labor force participation rates. The FLFP for India and Bangladesh is more than twice that of Pakistan. It is rather surprising that in spite of being a conservative Muslim nation, Bangladesh has the highest level of FLFP in the region.

One critical factor according to the Human Development for South Asia (2003) Report is the inclusion of data on casual workers. According to this report, India and Bangladesh are the only South Asian countries that include data on casual workers. Informal wage employment is estimated to account for $30-40 \%$ of informal employment in the non agricultural sector. Hence, it may be inferred that the reported levels of FLFP for India and Bangladesh are high due to this factor.

One major determinant of FLFP is the literacy rate. ${ }^{13}$ Interestingly, however, the female literacy rate of Bangladesh is lowest in the region. A trivial conclusion can therefore be that the female labor force participation is not strictly dependent on the female literacy rate. Hence it is important to analyze other factors that may account for the differing levels of FLFP.

Bangladesh is a poor country, and has suffered major political and economic turmoil since the time of its independence. The level of poverty is considerably higher in this region. Women belonging to the poorer households are more likely to engage in economic activity particularly in Bangladesh. Bangladesh has $15 \%$ households that are headed by women, compared to $10 \%$ in Pakistan and $9.1 \%$ in India. It is evident from our empirical findings that FLFP is positively related to the incidence of female

\footnotetext{
13 Female literacy rate: India 48.3\%, Pakistan 35.2\% and Bangladesh 31.8\%. UNESCO (2003-2004)
} 
headed households. Hence, the greater FLFP in Bangladesh probably owes a lot to the greater number of households headed by females.

The most important factor that accounts for high FLFP in Bangladesh may relate to the success of micro credit finance in the country. The outstanding success of the Grameen Bank has made it possible for many women, specifically in the rural areas, to earn a fair share of income. They use this income primarily for expenditure on food, clothes, health and the education of their children. Unfortunately, micro credit finance schemes have not been as successful in Pakistan as in Bangladesh. One factor responsible for this failure may be due to the non availability of donors, and the high default rate on the part of borrowers. Moreover, unlike Bangladesh, women may have shown less interest towards the micro credit schemes in Pakistan.

The fertility rate is inversely proportional to FLFP. Over the years fertility rates have considerably decreased in India and Bangladesh. However, the fertility rate for Pakistan is still very high. Hence this might be a vital factor that accounts for the disparity between the FLFP in India, Bangladesh and Pakistan.

\section{Conclusion and Policy Implications}

The paper has identified and analyzed the major determinants of female labor force participation in Pakistan with special reference to rural and urban areas. For this purpose, data on women (aged 15-49), from the PSLM Survey (2004-2005), has been analyzed using the Probit and Logit regression models. The empirical results of the study suggest that for women, higher educational attainment leads to greater participation in the labor force. The results suggest that there is a greater probability that a woman with the characteristics of being educated and unmarried would be a part of the labor force. On the basis of the empirical results, it has been observed that if a woman belongs to a nuclear family, has access to a vehicle, and has fewer children, then she is more likely to participate in the labor force. On the other hand, if the family size is large and she belongs to an extended family, she would be less likely to enter into the labor force. If the number of infants and children per female is small, female participation increases, whereas with a large number of children the probability of participating in the work force decreases. Moreover, the availability of home appliances reduces the probability of female participation in the labor force. 
In light of the findings of this study, the following are some suggestions and policy implications to improve the social status of rural and urban female regarding the labor force participation:

Reviewing the facts stated in the data regarding the proportion of females participating in the labor market with respect to education level, it has been surprisingly observed that $70 \%$ of our female labor force is illiterate, they have never attended school and of the remaining 30\%, 11\% have completed education up to matric, $9 \%$ primary, $3 \%$ higher education and $7 \%$ up to graduation. It is an alarming situation and the need of the hour is to analyze the factors as to why female education is minimal. Education plays a vital role in the development of societies and only educated females can understand their rights since education empowers a woman to make decisions regarding labor force participation.

As compared to urban areas, there are limited opportunities for education in rural areas. In rural areas women mostly work in the fields.

Women should also be encouraged to obtain technical education. In this regard certain programmes should be initiated so that they can contribute towards development.

The proper utilization of human and financial resources is lacking in our society. The solution to the problem lies in spreading awareness among the parents and husbands of females. The entry of females in the labor market fundamentally changes the status of females in their families as well as in society. 


\section{References}

Bailey, Martha J., 2004, "More Power to the Pill: The Impact of Contraceptive Freedom on Women's Labor Supply," Draft, University of Michigan.

Bradbury, Katharine and Jane Katz, 2005, "Women's Rise," Federal Reserve Bank of Boston Regional Review, Vo1.14, No. 3:58-67.

C. E. Metcalf, 1973, "Making Inferences from Controlled Income Maintenance Experiments", American Economic Review, (June), 63: 478-483.

Cain, Glen G. and Martin D. Dooley, 1976, "Estimation of a Model of Labor Supply, Fertility and Wages of Married Women”, Journal of Political Economy 84 (August): 179-199.

Duleep, Harriet and Sanders, Seth, 1994, "Empirical Regularities Across Cultures: The Effect of Children on Women's Work", The Journal of Human Resources, Vo1. 29, No.2: 328-347.

Greene, W.H., 1981, "Sample Selection Bias as a Specification Error: Comment”, Econometrica 49: 795-798.

Hausman, J., 1986, “Taxes and Labor Supply", In A. Auerbach and M. Feldstein eds, Handbook of Public Economics (Amsterdam: NorthHolland).

Heckman, J.J., 1979, "Sample Selection Bias as a Specification Error", Econometrica 47, 153-161.

Hill, M. Anne, 1983, "Female Labor Force Participation in Developing and Developed Countries: Consideration of the Informal Sector”, Review of Economics and Statistics 65 (August): 459-468.

Hotchkiss, Julie. L., Mary Melinda Pitts, 2005, Female labor force intermittency and current earnings: Switching regression model with unknown sample selection. Applied Economics, Vol. 37, No.5:545-60. 
Keeley, Michael C., 1978, "The Estimation of Labor Supply Models Using Experimental Data", The American Economic Review, Vol.68, No.5 (December):873-887.Killingsworth, Mark R., 1983, "Labor Supply”. New York: Cambridge University Press.

Koze1, V.,and H.Alderman, 1990, "Factors Determining Work Participation and Labor Supply Decisions in Pakistan's Urban Areas," The Pakistan Development Review 29(1):1-18.

Kurz, M. et al., 1974, "A Cross Sectional Estimation of Labor Supply for Families in Denver 1970,” Res. Memo. No. 24, Centre Study Welfare Policy, SRI International.

Malik, et a1., 1994, Determinants of Women Time Allocation in selected Districts of Rural Pakistan. The Pakistan Development Review $33: 4$.

Metcalf, C. E., 1973, "Making Inferences from Controlled Income Maintenance Experiments," American Economic Review, Vol. 63: 478-483.

Mincer,J, Ofek. H., 1962, "The Distribution of Lifetime Labor Force Participation of Married Women," The Journal of Political Economy, Vo1.87, No.1 pp.197-201.

Mroz, Thomas, 1987, "The Sensitivity of an Empirical Model of Married Women's Hours of Work to Economic and Statistical Assumptions," Econometrica, Vo1. 55, No.4, 765-799.

Nakamura, Alice and Masao Nakamura, 1981, "A Comparison of the Labor force Behavior of Married Women in the United States and Canada, with Special Attention to the impact of Income Taxes," Econometrica, Vo1. 49 (March): 451-489.

Nakamura, Masao, Alice Nakamura and Dallas Cullen, 1979, "Job Opportunities, the Offered Wage and the Labor Supply of Married Woman,” American Economic Review Vol. 69: 787-805.

Nakamura, Alice and Masao Nakamura, 1983, "Part Time and Full Time Work Behavior of Married Woman: A Mode1 with a Doubly Truncated Dependent Variable," The Canadian Journal of Economics, Vol.16, No.2:229-257. 
Naqvi, Zareen and Shahnaz, Lubna, 2002, "How do Women Decide to Work in Pakistan?” Working Paper.

Rashid, et.a1., 1989, "Women Labour Participation Behaviour: A case Study of Karachi," The Pakistan Journal of Applied Economics," Vo1. 8(2).

Robinson, C. and N. Tomes, 1985, "More on the Labor Supply of Women," The Canadian Journal of Economics, Vo1. 18: 156-163.

Shah N.M., 1986, "Changes in Women Role in Pakistan: Are the Volume and Pace Adequate?" The Pakistan Development Review, Vo1. 25(3).

Shimada, Haruo and Yoshio Higuchi, 1985, "An Analysis of Trends in Female Labor Force Participation in Japan," Journal of Labor Economics, Vol 3: 355-374.

Smith, J. Barry Morton S., 1988, "Labor Supply of Married Women in Canada, 1980", the Canadian Journal of Economics, Vol.21, No.4: 857-870.

Tadashi Yamada, Tetsuji Y. and Frank C., 1987, "Using Aggregate Data to Estimate the Part Time and Full Time Work Behavior of Japanese Women”, the Journal of Human Resources, Vo1.22, No.4: 574-583.

Tobin, J., 1958, "Estimation of Relationships for Limited Dependent Variables," Econometrica, Vol. 26: 24-36. 


\section{Appendix}

\section{Overall Pakistan}

Table 2.1: Descriptive Statistics

\begin{tabular}{lcccc}
\hline \multicolumn{5}{c}{ Number of Observations: 115077 } \\
\hline Age & Mean & Std Deviation & Minimum & Maximum \\
Marita1 & 28.164 & 9.727 & 15 & 49 \\
School & 0.665 & 0.472 & 0 & 1 \\
W_People & 3.165 & 4.470 & 0 & 19 \\
F_Size & 2.015 & 1.419 & 0 & 15 \\
F_Type & 8.105 & 3.843 & 1 & 54 \\
Vehic & 0.629 & 0.483 & 0 & 1 \\
Tech & 0.837 & 0.931 & 0 & 2 \\
F_Head & 0.709 & 0.859 & 0 & 4 \\
INF_F & 0.066 & 0.249 & 0 & 1 \\
INF_F2 & 1.101 & 1.182 & 0 & 10 \\
\hline
\end{tabular}




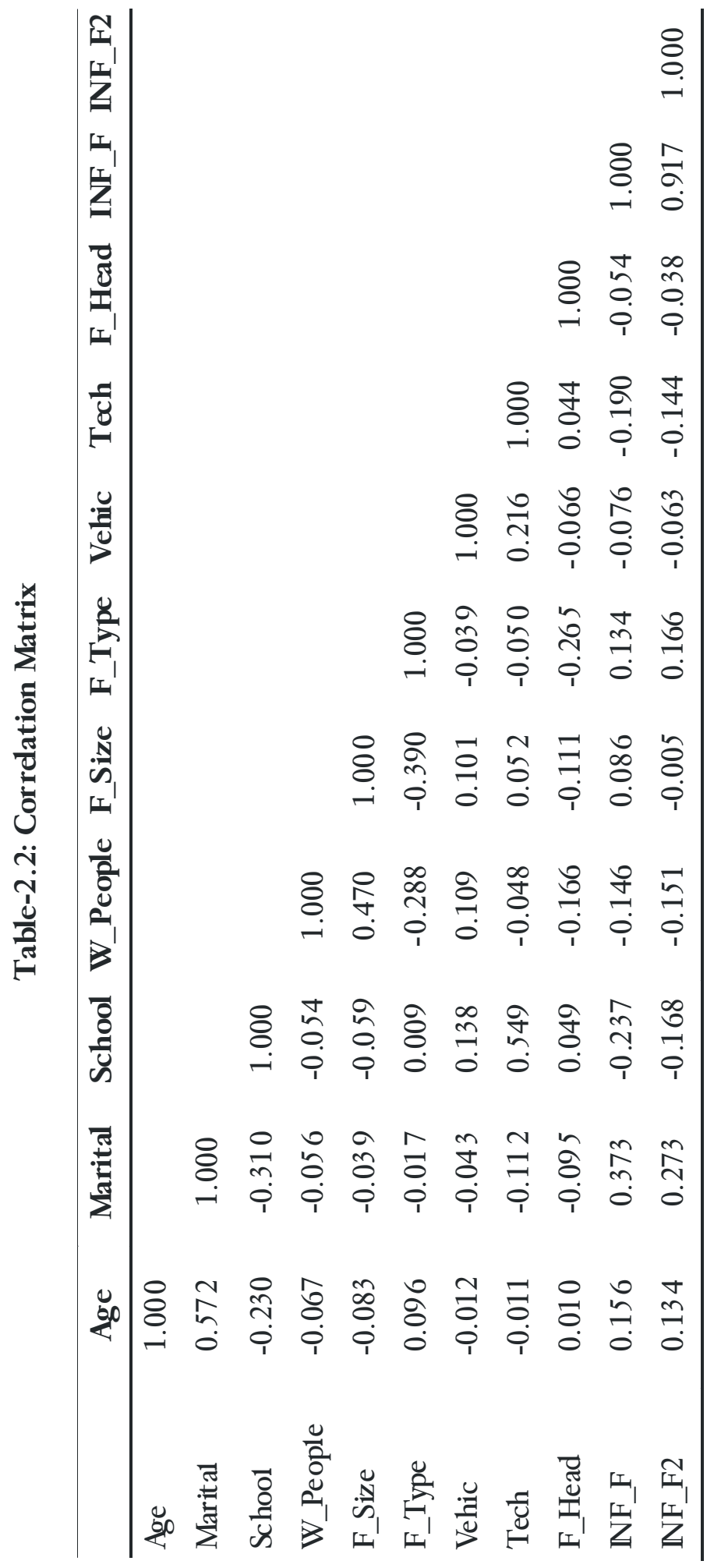


URBAN

Table-3.1: Descriptive Statistics(Urban)

\begin{tabular}{lcccc}
\hline \multicolumn{5}{c}{ Number of Observations: 42978 } \\
\hline Mean & Std Dev & Minimum & Maximum \\
\hline Age & 28.038 & 9.778 & 15 & 49 \\
Marital & 0.602 & 0.489 & 0 & 1 \\
School & 5.600 & 5.007 & 0 & 19 \\
W_People & 1.942 & 1.279 & 0 & 12 \\
F_Size & 7.926 & 3.545 & 1 & 36 \\
F_Type & 0.650 & 0.477 & 0 & 1 \\
Vehic & 0.005 & 0.072 & 0 & 1 \\
Tech & 1.190 & 0.957 & 0 & 3.6 \\
F_Head & 0.070 & 0.256 & 0 & 1 \\
INF_F & 0.908 & 1.093 & 0 & 10 \\
INF_F2 & 2.019 & 4.639 & 0 & 100 \\
\hline
\end{tabular}




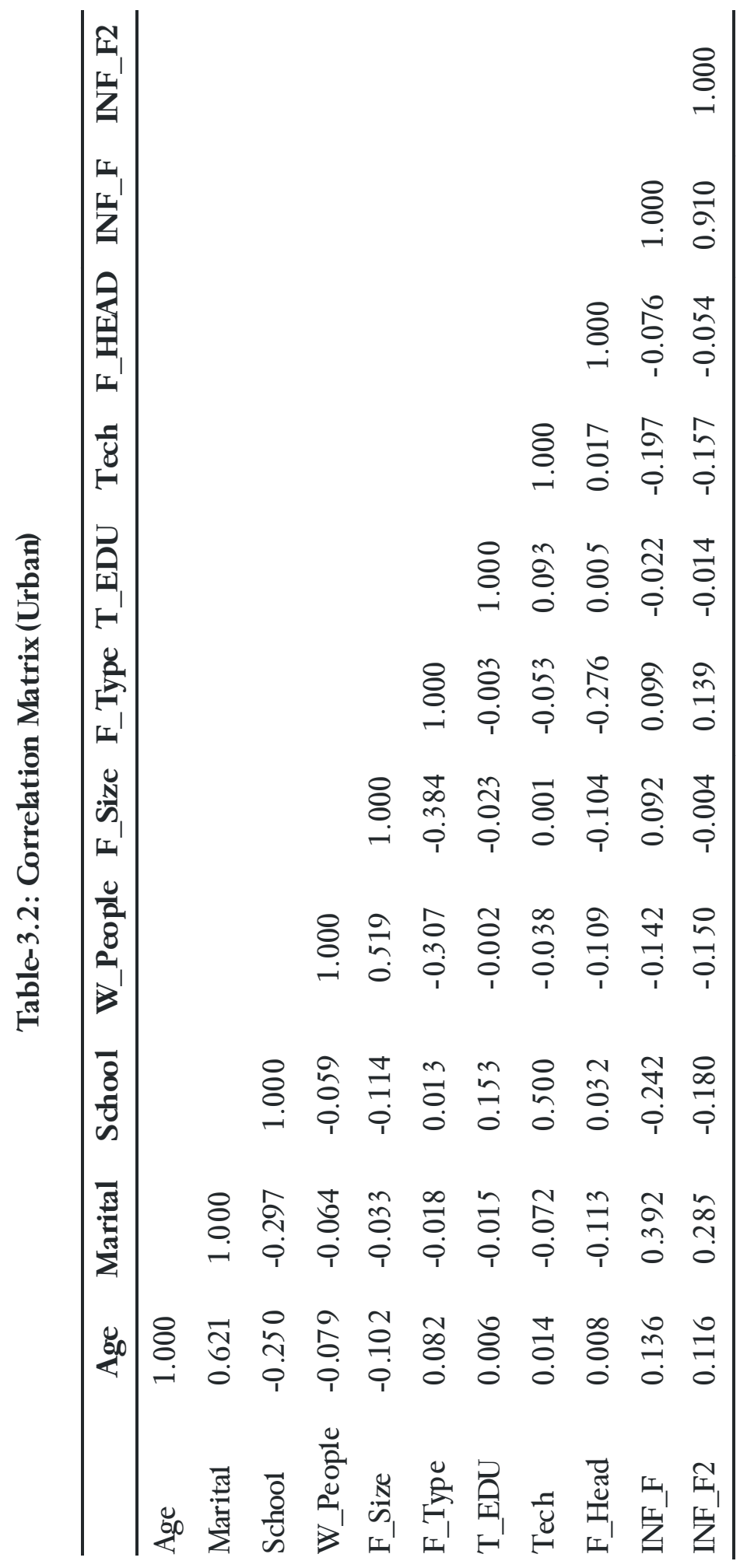


RURAL

Table-4.1: Descriptive Statistics

\begin{tabular}{lcccc}
\hline \multicolumn{4}{c}{ Number of Observations: 72099 } & \\
\hline & Mean & Std Dev & Minimum & Maximum \\
\hline Age & 28.238 & 9.697 & 15.000 & 49.000 \\
Marital & 0.703 & 0.457 & 0.000 & 1.000 \\
School & 1.714 & 3.362 & 0.000 & 19.000 \\
W_People & 2.059 & 1.495 & 0.000 & 15.000 \\
F_Size & 8.212 & 4.006 & 1.000 & 54.000 \\
F_Type & 0.617 & 0.486 & 0.000 & 1.000 \\
Asset_AG & 3.441 & 18.464 & 0.000 & 825.000 \\
Cattle & 11.148 & 1740.926 & 0.000 & 411212.0 \\
Vehic & 0.776 & 0.938 & 0.000 & 2.000 \\
Tech & 0.422 & 0.641 & 0.000 & 3.600 \\
F_Head & 0.064 & 0.244 & 0.000 & 1.000 \\
INF_F & 1.216 & 1.217 & 0.000 & 9.000 \\
INF_F2 & 2.958 & 5.700 & 0.000 & 81.000 \\
\hline
\end{tabular}




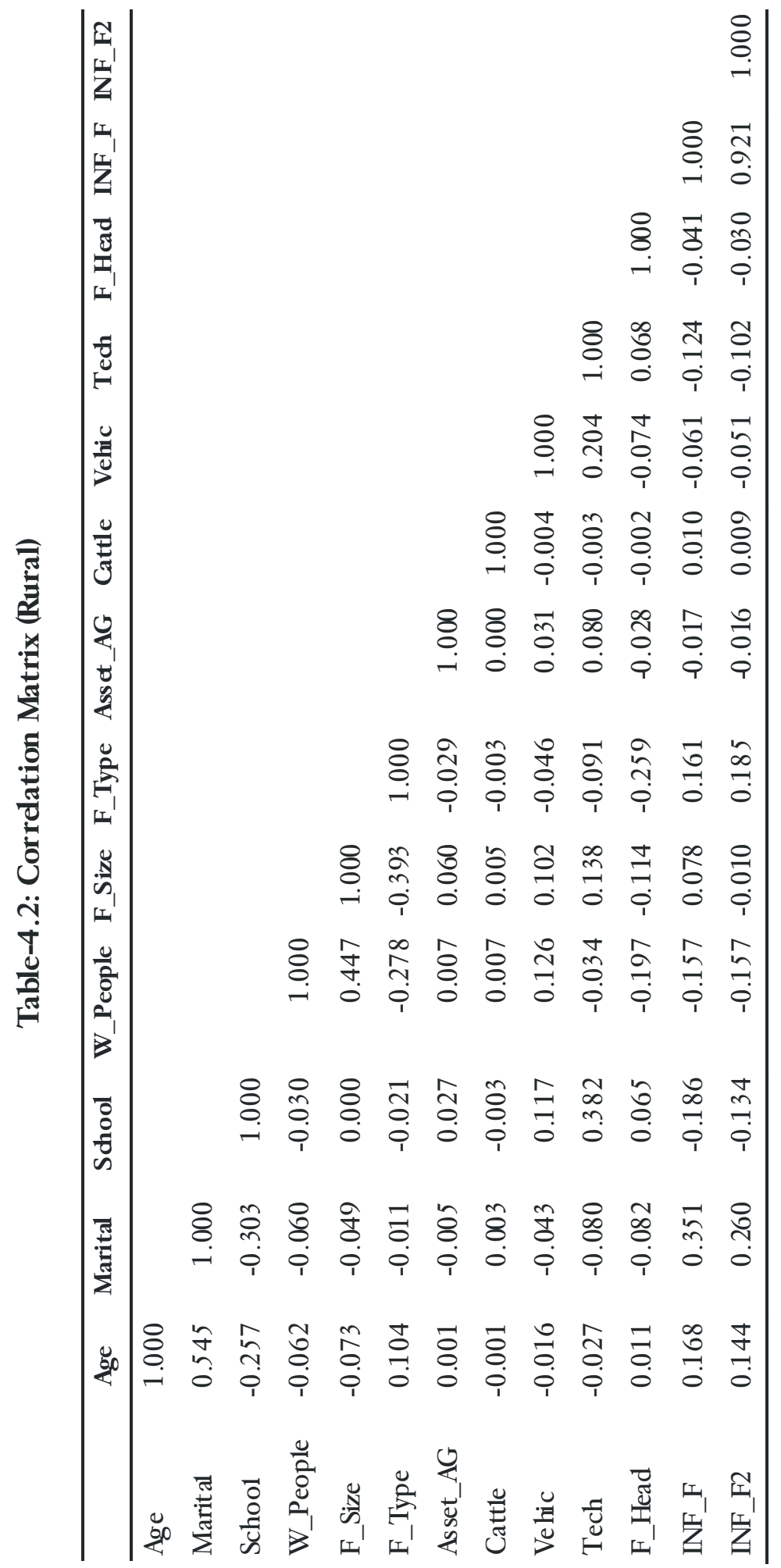


Pakistan (Probit)

Dependent variable: LFP

Number of observations $=115077$ Scaled R-squared $=.168659$

Number of positive obs. $=16801 \quad$ LR (zero slopes) $=19060.7$ [.000]

Mean of dep. var. $=.145998 \quad$ Schwarz B.I.C. $=38377.5$

Sum of squared residuals $=11136.7 \quad$ Log likelihood $=-38307.6$

R-squared $=.225859$

Fraction of Correct Predictions $=0.871929$

\begin{tabular}{lcccc}
\hline \multicolumn{1}{c}{ Parameter } & Coefficients & S. Error & t-statistic & P-value \\
C & -1.878 & 0.0265 & -70.96 & {$[.000]$} \\
Age & 0.017 & 0.0006 & 26.29 & {$[.000]$} \\
Marital & -0.214 & 0.0150 & -14.29 & {$[.000]$} \\
Schoo1 & 0.022 & 0.0015 & 14.75 & {$[.000]$} \\
W_People & 0.511 & 0.0044 & 116.06 & {$[.000]$} \\
F_Size & -0.134 & 0.0021 & -65.33 & {$[.000]$} \\
F_Type & 0.097 & 0.0128 & 7.54 & {$[.000]$} \\
Vehic & 0.072 & 0.0055 & 13.04 & {$[.000]$} \\
Tech & -0.235 & 0.0082 & -28.66 & {$[.000]$} \\
F_Head & 0.497 & 0.0221 & 22.49 & {$[.000]$} \\
INF_F & 0.365 & 0.0123 & 29.74 & {$[.000]$} \\
INF_F2 & -0.044 & 0.0025 & -17.26 & {$[.000]$} \\
\hline
\end{tabular}

Note.

$\beta(\mathrm{C})=$ Estimated logistic coefficient of each variable (it can be interpreted as the changein the log odds associated with a one-unit change in the independent variable)

S.E $=$ Standard error of estimates

Sig = Significance value or $\mathrm{p}$ value $\{$ this value is compared with the significance level $(\alpha)$ to determine whether each independent variable is significant or not in the model. If the significance $(\mathrm{p})$ value of a variable is less than the designated value of $\alpha(1 \%$ or $5 \%$ or $10 \%)$, the corresponding variable is significant $\}$

$R_{I}=$ partial correlation associated with the explanatory variable I, its value represents how much each variable contributes in this model. 
PAKISTAN (logit)

Dependent variable: LFP

Number of observations $=115077$ Scaled R-squared $=.177273$

Number of positive obs. $=16801 \quad$ LR (zero slopes) $=20014.6$ [.000]

Mean of dep. Var. $=.145998 \quad$ Schwarz B.I.C. $=37900.6$

Sum of squared residuals $=10972.2 \quad$ Log likelihood $=-37830.7$

R-squared $=.236099$

Number of Choices $=230154$

Fraction of Correct Predictions $=0.873511$

\begin{tabular}{lcccc}
\hline \multicolumn{1}{c}{ Parameter } & Coefficients & S. Error & t-statistic & P-value \\
\hline C-1 & -3.2658 & 0.0507 & -64.45 & {$[.000]$} \\
Age-1 & 0.0309 & 0.0012 & 26.37 & {$[.000]$} \\
Marital-1 & -0.4253 & 0.0279 & -15.26 & {$[.000]$} \\
School-1 & 0.0462 & 0.0027 & 16.80 & {$[.000]$} \\
W_People-1 & 0.9936 & 0.0089 & 112.12 & {$[.000]$} \\
F_Size-1 & -0.2892 & 0.0043 & -67.13 & {$[.000]$} \\
F_Type-1 & 0.2193 & 0.0242 & 9.05 & {$[.000]$} \\
Vehic-1 & 0.1191 & 0.0102 & 11.67 & {$[.000]$} \\
Tech-1 & -0.4283 & 0.0157 & -27.25 & {$[.000]$} \\
F_Head-1 & 0.9708 & 0.0402 & 24.13 & {$[.000]$} \\
INF_F-1 & 0.7535 & 0.0231 & 32.58 & {$[.000]$} \\
INF_F2-1 & -0.0892 & 0.0048 & -18.46 & {$[.000]$} \\
\hline
\end{tabular}




\section{Urban (Probit)}

Dependent variable: LFP

Number of observations $=42978$ Scaled R-squared $=.162052$

Number of positive obs. $=3945 \quad$ LR (zero slopes) $=6601.35$ [.000]

Mean of dep. Var. $=.091791 \quad$ Schwarz B.I.C. $=9943.07$

Sum of squared residuals $=2819.15 \quad$ Log likelihood $=-9879.06$

R-squared $=.213285$

Fraction of Correct Predictions $=0.913630$

\begin{tabular}{lcccc}
\hline \multicolumn{1}{c}{ Parameter } & Coefficients & S. Error & t-statistic & P-value \\
\hline C & -2.7199 & 0.0575 & -47.32 & {$[.000]$} \\
Age & 0.0321 & 0.0013 & 24.54 & {$[.000]$} \\
Marita1 & -0.4953 & 0.0292 & -16.98 & {$[.000]$} \\
School & 0.0574 & 0.0024 & 23.54 & {$[.000]$} \\
W_People & 0.6358 & 0.0099 & 64.53 & {$[.000]$} \\
F_Size & -0.1777 & 0.0046 & -38.85 & {$[.000]$} \\
F_Type & 0.2203 & 0.0250 & 8.80 & {$[.000]$} \\
T_EDU & 0.7066 & 0.0984 & 7.18 & {$[.000]$} \\
Tech & -0.1717 & 0.0126 & -13.58 & {$[.000]$} \\
F_Head & 0.6031 & 0.0380 & 15.86 & {$[.000]$} \\
INF_F & 0.4451 & 0.0257 & 17.30 & {$[.000]$} \\
INF_F2 & -0.0551 & 0.0058 & -9.48 & {$[.000]$} \\
\hline
\end{tabular}




\section{Urban (logit)}

Dependent variable: LFP

Number of observations $=42978 \quad$ Scaled R-squared $=.163745$

Number of positive obs. $=3945 \quad$ LR (zero slopes) $=6666.41$ [.000]

Mean of dep. Var. $=.091791$ Schwarz B.I.C. $=9910.55$

Sum of squared residuals $=2798.93 \quad$ Log likelihood $=-9846.53$

R-squared $=.218812$

Number of Choices $=85956$

Fraction of Correct Predictions $=0.915282$

\begin{tabular}{lcccc}
\hline \multicolumn{1}{c}{ Parameter } & Coefficients & S. Error & t-statistic & P-value \\
\hline C-1 & -4.8093 & 0.1135 & -42.37 & {$[.000]$} \\
Age-1 & 0.0606 & 0.0025 & 24.35 & {$[.000]$} \\
Marita1-1 & -0.9739 & 0.0561 & -17.35 & {$[.000]$} \\
School-1 & 0.1143 & 0.0048 & 23.90 & {$[.000]$} \\
W_People-1 & 1.2245 & 0.0196 & 62.35 & {$[.000]$} \\
F_Size-1 & -0.3779 & 0.0097 & -39.04 & {$[.000]$} \\
F_Type-1 & 0.4096 & 0.0485 & 8.45 & {$[.000]$} \\
T_EDU-1 & 1.2477 & 0.1705 & 7.32 & {$[.000]$} \\
Tech-1 & -0.3332 & 0.0247 & -13.51 & {$[.000]$} \\
F_Head-1 & 1.1017 & 0.0709 & 15.54 & {$[.000]$} \\
INF_F-1 & 0.9284 & 0.0511 & 18.16 & {$[.000]$} \\
INF_F2-1 & -0.1156 & 0.0120 & -9.66 & {$[.000]$} \\
\hline
\end{tabular}




\section{Rural (probit)}

Dependent variable: LFP

Number of observations $=72099 \quad$ Scaled R-squared $=.178171$

Number of positive obs. $=12856 \quad$ LR (zero slopes) $=12765.2$ [.000]

Mean of dep. Var. $=.178310 \quad$ Schwarz B.I.C. $=27497.3$

Sum of squared residuals $=8155.51 \quad$ Log likelihood $=-27419.0$

R-squared $=.230158$

Fraction of Correct Predictions $=0.848888$

\begin{tabular}{lcccc}
\hline \multicolumn{1}{c}{ Parameter } & Coefficient & S. Error & t-statistic & P-value \\
\hline C & -1.7562 & 0.0308 & -57.01 & {$[.000]$} \\
Age & 0.0130 & 0.0007 & 17.40 & {$[.000]$} \\
Marita1 & -0.1380 & 0.0179 & -7.70 & {$[.000]$} \\
Schoo1 & 0.0138 & 0.0021 & 6.56 & {$[.000]$} \\
W_People & 0.4832 & 0.0050 & 96.07 & {$[.000]$} \\
F_Size & -0.1230 & 0.0024 & -52.35 & {$[.000]$} \\
F_Type & 0.0974 & 0.0154 & 6.33 & {$[.000]$} \\
Asset_AG & 0.0027 & 0.0003 & 8.91 & {$[.000]$} \\
Cattle & 0.0010 & 0.0002 & 4.88 & {$[.000]$} \\
Vehic & 0.0992 & 0.0065 & 15.24 & {$[.000]$} \\
Tech & -0.2062 & 0.0120 & -17.25 & {$[.000]$} \\
F_Head & 0.4812 & 0.0279 & 17.27 & {$[.000]$} \\
INF_F & 0.3410 & 0.0143 & 23.77 & {$[.000]$} \\
INF_F2 & -0.0407 & 0.0029 & -14.03 & {$[.000]$} \\
\hline
\end{tabular}




\section{Rural (logit)}

Dependent variable: LFP

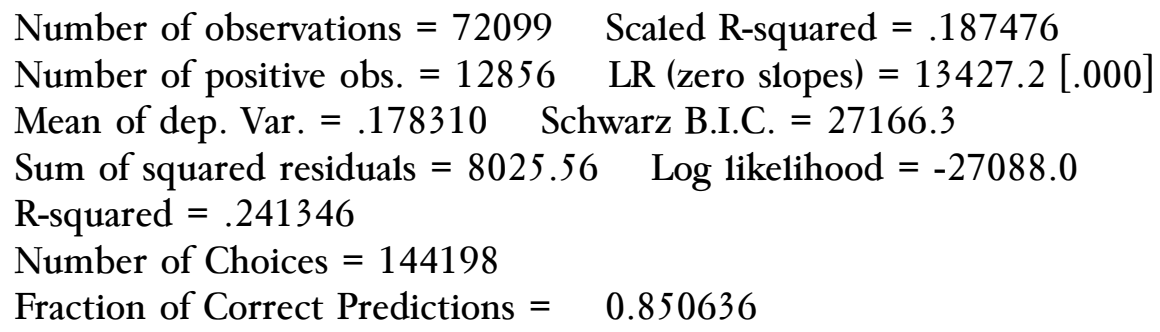

\begin{tabular}{lcccc}
\hline \multicolumn{1}{c}{ Parameter } & Coefficients & S. Error & t-statistic & P-value \\
\hline C-1 & -3.0386 & 0.0580 & -52.37 & {$[.000]$} \\
Age-1 & 0.0236 & 0.0013 & 17.50 & {$[.000]$} \\
Marital-1 & -0.2754 & 0.0328 & -8.40 & {$[.000]$} \\
School-1 & 0.0321 & 0.0039 & 8.28 & {$[.000]$} \\
W_People-1 & 0.9234 & 0.0100 & 92.35 & {$[.000]$} \\
F_Size-1 & -0.2584 & 0.0048 & -53.74 & {$[.000]$} \\
F_Type-1 & 0.2234 & 0.0286 & 7.82 & {$[.000]$} \\
Asset_AG-1 & 0.0041 & 0.0005 & 7.43 & {$[.000]$} \\
Catt1e-1 & 0.0016 & 0.0007 & 2.23 & {$[.026]$} \\
Vehic-1 & 0.1632 & 0.0118 & 13.81 & {$[.000]$} \\
Tech-1 & -0.3675 & 0.0226 & -16.24 & {$[.000]$} \\
F_Head-1 & 0.9549 & 0.0502 & 19.03 & {$[.000]$} \\
INF_F-1 & 0.6873 & 0.0264 & 26.02 & {$[.000]$} \\
INF_F-21 & -0.0807 & 0.0054 & -15.04 & {$[.000]$} \\
\hline
\end{tabular}

